\title{
Editorial: Knowledge is Power, Ignorance is Bliss: Public perceptions and responses to human trafficking
}

\author{
Kiril Sharapov, Suzanne Hoff and Borislav Gerasimov
}

Please cite this article as: K Sharapov, S Hoff and B Gerasimov, 'Editorial: Knowledge is Power, Ignorance is Bliss: Public perceptions and responses to human trafficking', Anti-Trafficking Review, issue 13, 2019, pp. 1-11, https://doi. org/10.14197/atr.201219131

'Scientia potentia est', or 'knowledge is power', a quote commonly attributed to sixteenth-century English philosopher and statesman Francis Bacon, has become a popular axiom for the transformative power of learning and knowledge. In his address to the 1997 World Bank Conference 'Global Knowledge 97', Kofi Annan, the then Secretary-General of the United Nations, proclaimed that knowledge was, indeed, power, and that information was liberating. ${ }^{1}$ However, a more critical stance on what constitutes knowledge (including the questions of what we know and how we know it) by some of the key philosophers of the twentieth century, including Althusser, Foucault and Bourdieu, and, recently, scholars focussing on the study of ignorance, have highlighted the complexities of power relations that underpin both the spatialities and temporalities of knowledge production, distribution and manipulation. One of the key questions for agnotology-a study of manufactured and productive ignorance-is not just 'how we know' but ' why don't we know what we don't know?'. ${ }^{2}$ It suggests that power sits not with those in possession of knowledge, but with those in control of its production and distribution. These questions are equally important in the field of human trafficking as academic, political and public interest in the issue has grown exponentially over the past two decades.

1 United Nations, Press Release SG/SM/6268, 23 June 1997, https://www.un.org/press/ en/1997/19970623.sgsm6268.html.

2 R Proctor, 'Agnotology: A missing term to describe the cultural production of ignorance (and its study)' in R Proctor and L Schiebinger (eds.), Agnotology: The making and unmaking of ignorance, Stanford University Press, Stanford, 2008, pp. 1-33.

This is an open-access article distributed under the terms of the Creative Commons Attribution License (CC-BY). Under the CC-BY license, the public is free to share, adapt, and make commercial use of the work. Users must always give proper attribution to the authors and the Anti-Trafficking Review. 


\section{Raising Awareness: Of whom? Of what?}

The focus of this issue of the Anti-Trafficking Review-public perceptions and responses to human trafficking-reflects the growing unease and disagreements among anti-trafficking practitioners and scholars about the current state of public awareness of human trafficking: how and by whom such awareness is produced and manipulated, whom it is targeting, and whether it leads, or can lead, to any meaningful anti-trafficking action. ${ }^{3}$ A central assumption in the anti-trafficking field is that the general public still lacks sufficient knowledge about human trafficking, and that creating more knowledge and awareness will lead to its reduction. ${ }^{4}$ However, there neither exists a common understanding of who should know what in order to achieve this goal, nor is there sufficient information available about the awareness of the general public or, especially, the impact of this awareness.

Moreover, acknowledging the heterogeneity of public opinion, the diversity of cultural, socio-economic and political contexts in which individual perceptions are formed and responses are enacted, one of the key messages that runs through the contributions in this issue is that public awareness of 'wicked' social problems ${ }^{5}$ (including issues that are directly experienced by only a small proportion of the general public) does not emerge out of nowhere-it is actively manufactured, sustained and manipulated by those in the position of economic and political power to set the agenda.

While we were working on this issue, the European Commission allocated a multi-million euro budget towards 'raising awareness of the risks of smuggling and irregular migration... [to prevent]...prospective migrants and asylum seekers

3 See, for example: K Kempadoo, 'The Modern White (Wo)Man's Burden: Trends in anti-trafficking and anti-slavery campaigns', Journal of Human Trafficking, vol. 1, issue 1, 2015, pp. 8-20, https://doi.org/10.1080/23322705.2015.1006120; E O’Brien, Challenging the Human Trafficking Narrative: Victims, villains, and heroes, Routledge, New York, 2019; K Sharapov and J Mendel, 'Trafficking in Human Beings: Made and cut to measure? Anti-trafficking docufictions and the production of anti-trafficking truths', Cultural Sociology, vol. 12, no. 4, 2018, pp. 540-560, https://doi.org/10.1177/ 1749975518788657.

4 For example, out of 43 prevention initiatives reviewed by a 2015 European Commission study, 39 referred to raising awareness as one of their objectives. See: European Commission, Study on Prevention Initiatives on Trafficking in Human Beings: Final report, Brussels, 2015, retrieved 10 April 2019, https://ec.europa.eu/anti-trafficking/ sites/antitrafficking/files/study_on_prevention_initiatives_on_trafficking_in_human_beings_0.pdf.

5 B W Head, 'Wicked Problems in Public Policy', Public Policy, vol. 3, issue 2, 2008, pp. 101-118. 
[from Africa, Asia and Eastern Europe], ... from embarking on hazardous journeys towards the EU'. 'Such an extraordinary hollowing out and folding of the unwanted non-European Others and of their extraordinary suffering along the borders of 'Fortress Europe' into an issue of their poor awareness (where 'negative information [about Europe] presented in campaigns was either not believed, or was insufficient to overcome the appeal of the alternative positive information presented by friends, family or smugglers ${ }^{7}$ ) reasserts and re-establishes the relationship of differentiated belonging and abandonment across the neoliberal world, in which the mobility of some is restrained 'in order to enable freedom for others' ${ }^{8}$

At the same time, in the United States, President Trump used the imagery of women and girls 'tied up in the backseat of a car' and 'with tape on their mouth' to consolidate the public imaginary of a national emergency at the US-Mexico border to secure public support and funds for a border wall to 'protect' the country from an 'invasion' of migrants and asylum seekers from Latin America. ${ }^{9}$ This reflects the common portrayal in the media of human trafficking as an issue of sexual exploitation of women, ${ }^{10}$ as opposed to other, less salacious, forms of exploitation. This focus on migration and sex work and the simplification of the nature of the problem feed into a broader battle of 'storytelling about migrants'-a battle fought 'today in the public squares, at political conventions, on the

6 European Commission, 'Awareness raising and information campaigns on the risks of irregular migration in selected third countries and within Europe', Single Electronic Data Interchange Area, European Commission, 2019, https://ec.europa.eu/info/ funding-tenders/opportunities/portal/screen/opportunities/topic-details/amif-2019ag-call-04.

7 Ibid., p. 3.

8 J Engelbert, I Awad and J van Sterkenburg, 'Everyday Practices and the (Un)making of "Fortress Europe": Introduction to the special issue', European Journal of Cultural Studies, vol. 22, issue 2, 2019, pp. 133-143, https://doi.org/10.1177/1367549418823055 and other articles in the special issue exploring how borders of Europe are erected and guarded through cultural practices, border control and security technologies.

9 D Trump, 'Remarks by President Trump on the National Security and Humanitarian Crisis on our Southern Border,' White House, Rose Garden, 15 February 2019, retrieved 22 August 2019, https:/www.whitehouse.gov/briefings-statements/remarks-presidenttrump-national-security-humanitarian-crisis-southern-border.

10 See, among others: T Bonilla and C H Mo, 'The Evolution of Human Trafficking Messaging in the United States and its Effect on Public Opinion', Journal of Public Policy, vol.39, issue 2, 2019, pp. 201-234, https://doi.org/10.1017/S0143814X18000107 and R Andrijasevic and N Mai, 'Editorial: Trafficking (in) Representations: Understanding the recurring appeal of victimhood and slavery in neoliberal times', Anti-Trafficking Review, issue 7, 2016, pp. 1-10, https://doi.org/10.14197/atr. 20121771. 
television, in the opinion pages. ${ }^{11}$

From a practical point of view, having some degree of awareness is better than having none. However, the very notion of awareness, which informs public perceptions and, as a consequence, results in individual and public responses to human trafficking (or lack thereof), can never be static. It should be recognised and treated as a process, or a continuum, rather than a binary state of being fully aware or fully unaware - an approach adopted within much of the increasing and diverse anti-trafficking awareness-raising. This now includes human trafficking songs, ${ }^{12}$ mobile applications, ${ }^{13}$ computer games, ${ }^{14}$ 'docufictions',${ }^{15}$ feature films, ${ }^{16}$ theatre, ${ }^{17}$ opera, ${ }^{18}$ dance projects ${ }^{19}$ and other forms of popular culture.

Awareness-raising and information provision is the most common tool in the arsenal of prevention activities (one of the main pillars of anti-trafficking responses, described as the 'three Ps' of prevention, prosecution and protection). However, it remains grounded in the binary of aware/unaware and informed/uninformed, without recognition that people may be aware of human trafficking (or their rights in the context of labour migration) but their ability to act on such information/awareness may be severely constrained by external factors, including

11 S Mehta, 'Immigration Panic: How the west fell for manufactured rage', The Guardian, 27 August 2019, https://www.theguardian.com/uk-news/2019/aug/27/immigrationpanic-how-the-west-fell-for-manufactured-rage.

12 See, for example, a YouTube channel, dedicated to 'human trafficking songs': https:// www.youtube.com/playlist?list=PL4-42hn_MPYD1MfmFUpXLIk2wSZNi8CC4.

13 J Mendel and K Sharapov (forthcoming), “"Stick them to the Cross”: Anti-trafficking apps and the production of ignorance'.

14 E O'Brien and $\mathrm{H}$ Berents, 'Playing games with child trafficking in India', Open Democracy, 24 May 2018, https://www.opendemocracy.net/en/beyond-traffickingand-slavery/playing-games-with-child-trafficking-in-india, as well as E O'Brien and $\mathrm{H}$ Berents' article in this issue.

15 Sharapov and Mendel, 2018.

16 N de Villiers, 'Rebooting Trafficking', Anti-Trafficking Review, issue 7, 2016, pp. 161181, https://doi.org/10.14197/atr.20121779.

17 International Organization for Migration, “'A Theater against Human Trafficking” Project Launched in Peru', IOM, 11 August 2017, https:/www.iom.int/news/theater-against-human-trafficking-project-launched-peru.

18 E A Gordon, 'Human trafficking and sex slavery: The opera', People's World, 22 July 2016, https://www.peoplesworld.org/article/human-trafficking-and-sex-slavery-theopera.

19 The Natashas Project, https://www.thenatashasproject.co.uk/\#about. 
a lack of power. ${ }^{20}$

At the same time, like many of the dominant policy and legal anti-trafficking frameworks, awareness-raising remains unilinear, monological, teleological and extremely elastic. ${ }^{21}$ Its unilinear aspect is a one-directional future-facing goal of the 'fight against trafficking in human beings': more policing and raids; more border control; more prosecutions and convictions; more 'rescue' and more awareness. ${ }^{22}$ High-level policy aspirations to build 'a future without human trafficking ${ }^{23}$ often fail to recognise human trafficking as, first and foremost, an issue of social and economic justice, and of human rights, deeply rooted in the colonial past, and sustained in the post- and neo-colonial present by neoliberal structures of exploitation, and 'heavy, often violent, restraints on freedom in the contemporary world'. ${ }^{24}$ It is monological in claiming to be true for all victims (who are poor, uninformed, vulnerable, more often female, and in need of 'rescue', awareness and 'rehabilitation') and all members of the general public (who are nationals and should be 'the eyes and ears of their communities' and demand action by the authorities ${ }^{25}$ ). It is teleological in that it is aimed at a known outcome-no victims and no criminals as an ultimate and at-all-cost endpoint of the 'fight' against human trafficking rather than securing the rights of millions of migrant, female and low-wage workers moving within and across borders on a daily basis. It is elastic in that the endpoint is always near-just one more antitrafficking strategy, directive, conference, or an awareness campaign-yet the end

20 See, for example: T Blanchet and S K Watson, 'Learning to Swim in Turbulent Waters: Women's migration at the agency-exploitation nexus', Journal of Contemporary Asia, published online 8 July 2019, https://doi.org/10.1080/00472336.2019.1612935 and D Feingold, 'Raising awareness: of what? for what? by whom? for whom?', Open Democracy, 20 June 2019, https:/www.opendemocracy.net/en/beyond-traffickingand-slavery/raising-awareness-of-what-for-what-by-whom-for-whom.

21 Based on Deborah Bird Rose's discussion of time in relation to the concept of Anthropocene. D B Rose, 'Anthropocene Noir' in People and the Planet 2013 Conference Proceedings, RMIT University, 2013, retrieved 10 April 2019, http://global-cities.info/ wp-content/uploads/2014/05/Anthropocene-Noir.pdf.

22 See Sharapov and Mendel, 2018, commenting on the process of raising awareness through spectacle with the only call to action being one to raise awareness.

23 A Guterres, 'Remarks at Ministerial Open Debate on Trafficking in Persons in Conflict Situations: Forced labour, slavery and other similar practices', United Nations, 15 March 2017, https:/www.un.org/sg/en/content/sg/speeches/2017-03-15/trafficking-persons-conflict-situations-remarks.

24 J O'Connell Davidson, 'Editorial: The Presence of the Past: Lessons of history for anti-trafficking work', Anti-Trafficking Review, issue 9, 2017, pp. 1-12, p. 3, https:// doi.org/10.14197/atr.20121791.

25 United States Department of State, 2019 Trafficking in Persons Report, USDS, Washington DC, 2019, p. 12. 
of human trafficking never comes, calling, as a consequence, for more and more of the same. All this is despite the fact that so little is known about the impact of anti-trafficking measures, ${ }^{26}$ including awareness and information campaigns. ${ }^{27}$

\section{This Special Issue}

In setting out to develop this issue, we thought about a variety of dimensions and questions - from both scholarly and activist perspectives - that we hoped would help untangle the 'wicked' problem of public awareness and understanding of as well as responses to human trafficking. The final selection of articles-informed by robust empirical research—sets out a series of key findings that we hope will benefit not only practitioners, policy-makers and activists, but also members of the general public concerned about their role in eradicating human trafficking and exploitation.

The issue starts with a contribution by Lauren Martin and Annie Hill, who compiled a set of empirical data to challenge the common myth that large sporting events cause an increase in human trafficking for sexual exploitation. They highlight the need for reliable evidence in designing public awareness campaigns, and demonstrate the success of such an approach within the context of the 2018 Super Bowl in the US city of Minneapolis. The authors conclude that even in an age of 'fake news' and post-truth politics, a cross-stakeholder group comprising women's rights and anti-trafficking organisations, law enforcement, social service providers and academics, can commit to evidence-based and accurate communication about human trafficking, even when the evidence contradicts a dominant discourse.

The importance of empirical data is also highlighted by Kiril Sharapov, whose article focusses on the outcomes of three national opinion polls - one of the first attempts to capture representative snapshots of public opinion and understanding of human trafficking - in three European countries, Great Britain, Hungary and Ukraine. The outcomes of his research suggest that the general public in these three countries have a relatively high awareness, at least in general terms, of human trafficking. At the same time, this awareness reflects a simplistic interpretation of the issue as a criminal transaction between individual victims and individual

26 B Harkins, 'Constraints to a Robust Evidence Base for Anti-Trafficking Interventions', Anti-Trafficking Review, issue 8, 2017, pp. 113-130, https://doi.org/10.14197/ atr.20121787.

27 N Cyrus and D Vogel, 'Evaluation as Knowledge Generator and Project Improver. Learning from demand-side campaigns against trafficking in human beings', Contemporary Readings in Law and Social Justice, vol. 10, issue 1, 2018, pp. 57-93. 
criminals involving irregular border-crossing rather than an issue of social justice and human rights. Sharapov calls for further reliance on public opinion surveys as one of the approaches to evaluate the effectiveness and impact of awarenessraising campaigns.

In the next article, Peter Olayiwola analyses how ignorance finds its way into anti-trafficking awareness campaigns in the context of child domestic work in South-West Nigeria. The author highlights two types of ignorance: anti-trafficking activists' assumption of parents' and child domestic workers' ignorance about abuse and exploitation, and perceived opportunities within the context of child domestic work; and the ignorance of anti-trafficking activists themselves in relation to the root causes of trafficking, including economic inequalities, as key enablers of precarious migration journeys. Olayiwola concludes that information and 'awareness-creation' do nothing to address poverty and economic inequality and thus can have little, if any, impact on preventing trafficking-for child domestic work or otherwise.

For their part, Jen Birks and Alison Gardner examine the public perceptions of human trafficking and 'modern slavery' created by newspapers at the local level in the East Midlands region of the United Kingdom. Through a review of the coverage in five local newspapers, they find a gradual increase in the quantity and quality of articles on these subjects and a move away from coverage of trafficking in the sex industry to other labour sectors, such as agriculture, construction and manual labour. Birks and Gardner supplement these findings with the results of focus group discussions (FGD) with seventeen participants. The FGD data produces an important, if perhaps inconvenient, revelation for anti-trafficking campaigners: members of the general public in the region do not feel comfortable reporting potential cases of human trafficking and 'modern slavery'. This is because, first, the indicators promoted by 'spot the signs' campaigns are overly broad and vague and, secondly, because they worry that the UK's 'hostile environment' to migrants may result in the arrest and deportation of potential victims of trafficking, rather than their assistance and support.

In addition to the complexities of measuring the effectiveness of 'traditional' awareness-raising (such as media campaigns and public service announcements), this issue also draws attention to the emergence of new forms of anti-trafficking awareness-raising. The article by Erin O'Brien and Helen Berents focusses on digital games as a new form of 'virtual humanitarianism', which relies on digital technologies to convey narratives of suffering and humanitarian rescue. In doing so, they interrogate whether new technologies are used to present a new dimension to humanitarian problems, in this case human trafficking, or reinforce the old and problematic stereotypes of ideal victims and ideal criminals. Their review of three desktop and mobile games shows that games can achieve both; however, overall, despite their interactiveness, games have limited potential to tell complex stories, disrupt dominant narratives, and convey the idea that human trafficking 
is rooted in structural socio-economic and political issues.

The ignorance of the socio-economic and political issues - this time among corporate actors - that leave workers across the world vulnerable to exploitation is further developed in the article by Ilse A. Ras and Christiana Gregoriou. By focussing on corporate 'modern slavery' statements published by companies in response to the requirements of the UK Modern Slavery Act, Ras and Gregoriou analyse the role of metaphors embedded into such statements. They show how metaphors erase the complexity of the inherently exploitative nature of modern neoliberal supply chains from the public field of vision, and disenfranchise workers by casting aside their agency. This kind of individual and institutional erasure, where the need for structural interventions to secure human rights of workers is reduced to a set of specific linguistic narratives, reflects increasingly reactionary rather than preventative approaches that characterise so many anti-trafficking initiatives in the Global North.

The issue concludes with Jeremy Norwood's review of the book Trafficked Children and Youth in the United States: Reimagining Survivors by Elżbieta M. Goździak (Rutgers University Press, 2016). Norwood's review focusses on three important contributions that the book makes for anti-trafficking advocates and scholars: first, it highlights the economic, social and political root causes that underpin human trafficking; secondly, it reveals the complex interactions between victims and criminals, in particular in cases where minors were first smuggled to the United States and then exploited by their family or relatives; and lastly, it deconstructs many of the myths and assumptions about human trafficking evident in anti-trafficking campaigns and policies. Norwood also highlights the fact that the book is based on much-needed empirical work with trafficking survivors.

\section{Conclusion}

Although the articles in this special issue focus on different countries and communication mediums and strategies, ultimately, they all converge around one central message: overall, public perceptions of human trafficking - whether created by the media, NGOs, governments or corporations, and conveyed through campaigns, apps, newspapers or corporate statements-remain incomplete and, often, misleading regarding the nature of trafficking, its root causes and, consequently, its prevention.

Despite their diversity, most awareness-raising messages continue to deliver simplistic narratives of 'victims, villains, and heroes' ${ }^{28}$ while leaving the structural root causes of human trafficking and the systems of domination that underpin 
them intact. The failure to highlight these root causes removes the call for structural reforms from the public imagination and shifts accountability and responsibility away from governments. In response to this failure, and by drawing on the contributions in this issue, we offer a few suggestions for a way forward.

For one, anti-trafficking campaigners need to do a better job at drawing public attention to the root causes that render people vulnerable to trafficking and promoting measures that would address these root causes. The stereotypical narrative of 'she was looking for a better life' (and was lured by a trafficker into a life of exploitation) is not enough if precarious lives, in which 'insecurities, dangers and maybe termination are forever present', ${ }^{29}$ are not part of this narrative. Different narratives can lead to different solutions: rather than more antitrafficking manuals, committees, or inter-ministerial working groups, they would call for access to decent work in one's own country, for unemployment, old-age and child care benefits, and accessible and affordable hospitals and kindergartens. In fact, in some countries, it is 'possible that a kindergarten might do more to prevent trafficking than an anti-trafficking committee'. ${ }^{30}$ The link between the lack of social protections and underfunding of public services, on the one hand, and migration and (vulnerability to) trafficking on the other hand, especially for women, cannot be overstated, ${ }^{31}$ yet remains conspicuously absent from public inquiries. ${ }^{32}$

Anti-trafficking campaigns must also acknowledge the fact that human trafficking is not just caused by deviant individuals, 'traffickers, criminals, clients, pimps, corrupt immigration officers or policewomen or men, or greedy businesspeoplespecific "bad" corporations and companies that violate labor laws and codes of conduct, or isolated national governments', ${ }^{33}$ and that their criminalisation alone will not stop it. One of the key messages lacking from anti-trafficking awareness raising is that human trafficking is the result of a power imbalance between

29 C Philo, H Parr and O Söderström, “"On edge?”: Studies in precarious urbanisms', Geoforum, vol. 101, 2019, pp. 150-155, https://doi.org/10.1016/j.geoforum.2019.04.020.

30 B Gerasimov, 'Human Trafficking-From a criminal justice to social justice approach', Keynote speech delivered at the conference Disrupting Traffick?, University of Chicago Delhi Centre, New Delhi, India, 17 May 2019, https:/gaatw.org/advocacy/ DT-Keynote\%20Speech-BG.pdf.

31 Global Alliance Against Traffic in Women, Social Protection, Public Services, and Sustainable Infrastructure for Women Migrant Workers and Trafficked Persons, Background paper of the Global Alliance on Traffic in Women (GAATW) for the 63rd session of the Commission on the Status of Women (CSW), Bangkok, 2019, https:/gaatw.org/ advocacy/GAATW\%20Paper\%20Social\%20Protections\%20CSW\%2063.pdf.

32 F Mullin, 'How can the Tories' moralising report on prostitution completely ignore austerity?', The Guardian, 29 July 2019, https://www.theguardian.com/commentisfree/2019/jul/29/how-can-the-tories-moralising-report-on-prostitution-completely-ignore-austerity. See, also, more generally: S Walby, Crisis, Polity, Oxford, 2015.

33 Kempadoo, p. 16. 
employers and workers and the normalisation of workers' exploitation. Antitrafficking campaigns need to call for the recognition of and labour protections in unregulated sectors, such as domestic work and sex work; the adequate implementation of labour laws; and the strengthening of labour inspection systems across all sectors of the economy, so that working conditions can be effectively monitored and abuses reported. Such monitoring must be government and worker/union-led, and not the corporate and technology-led voluntary social audits (or 'modern slavery statements') promoted by anti-trafficking stakeholders despite their well-known inefficiency. ${ }^{34}$ Binding measures for the private sector, rather than requirements for symbolic statements, will bring more positive changes for workers.

Further, campaigns that expose the root causes of trafficking must be accompanied by calls for meaningful collective action by the public-not the clicktivism of taking selfies, liking and sharing, or dancing, singing and squatting against trafficking. These actions must also go beyond the perhaps more meaningful questioning of 'who made my clothes', ethical shopping for 'slavery-free' or fairtrade products, or pledges not to pay for sexual services. Those who truly care about ending trafficking and exploitation must not allow neoliberalism to con them into fighting them as individuals. ${ }^{35}$ People need to demand that their governments and the international community restrict the power of multi-national corporations, put an end to tax evasion, introduce progressive tax policies for the financing of public services, and enact labour and migration policies that work for the many, not the few.

Finally, we must be mindful of who speaks and who raises awareness of whom and on behalf of whom. Those of us who hold the power of production and distribution of knowledge must let the people in vulnerable and exploitative situations, or in irregular work, speak for themselves and demand the change they need. With their engagement, perceptions of human trafficking can change and knowledge can be built from the ground up.

34 P Kyritsis, G LeBaron and M Anner, 'New Buzzword, Same Problem: How 'worker voice' initiatives are perpetuating the shortcomings of traditional social auditing', Business and Human Rights Resource Centre, 12 March 2019, https://www.business-humanrights.org/en/new-buzzword-same-problem-how-worker-voice-initiatives-are-perpetuating-the-shortcomings-of-traditional-social-auditing.

35 Cf. with regard to climate change: M Lukacs, 'Neoliberalism has conned us into fighting climate change as individuals', The Guardian, 17 July 2017, https://www. theguardian.com/environment/true-north/2017/jul/17/neoliberalism-has-conned -us-into-fighting-climate-change-as-individuals. 
Kiril Sharapov is Associate Professor of Applied Social Sciences at Edinburgh Napier University. He received his $\mathrm{PhD}$ in Politics from the University of Glasgow, and an MA in Human Rights from the Central European University. Kiril's research interests include migration and mobility with a particular focus on human rights, trafficking in human beings and 'modern slavery', forced migration, free and unfree labour; as well as subjectivity, politics and neoliberalism; and environmental degradation and social divisions.Email: k.sharapov@napier.ac.uk

Suzanne Hoff is the International Coordinator of La Strada International-a European Platform against trafficking in human beings. In this role, she manages a broad range of tasks, including strategy planning, lobby and advocacy, monitoring of European developments in anti-trafficking policy, and coordination of research and advocacy projects, including on early identification of trafficked persons, cooperation among NGOs, trade unions and businesses, and access to compensation and remedies for workers. Suzanne has an academic background in East European studies and (television) journalism. Her previous work focused on human rights in Central and Eastern Europe. Email: sh@lastradainternational. org

Borislav Gerasimov is Communications and Advocacy Officer at the Global Alliance Against Traffic in Women and the Editor of the Anti-Trafficking Review. He holds a degree in English Philology from Sofia University St. Kliment Ohridski, Bulgaria and has previously worked at Animus Association, Bulgaria and La Strada International, the Netherlands. He has also been involved in the work of NGOs supporting Roma youth, LGBTI people, people living with HIV/AIDS, and sex workers in Bulgaria and the Netherlands. Email: borislav@gaatw.org 